\title{
On the Viennese Background of Harvard Neopragmatism
}

\section{Pihlström, Sami Johannes}

Springer

2017

Pihlström , S J 2017 , On the Viennese Background of Harvard Neopragmatism . in S

Pihlström , F Stadler \& N Weidtmann (eds), Logical Empiricism and Pragmatism . Vienna

Circle Institute Yearbook , vol. 19 , Springer , Dordrecht , pp. 139-166 . https://doi.org/10.1007/978-3-319-50730-9_8

http://hdl.handle.net/10138/310735

https://doi.org/10.1007/978-3-319-50730-9_8

acceptedVersion

Downloaded from Helda, University of Helsinki institutional repository.

This is an electronic reprint of the original article.

This reprint may differ from the original in pagination and typographic detail.

Please cite the original version. 


\title{
ON THE VIENNESE BACKGROUND OF HARVARD NEOPRAGMATISM
}

\author{
Sami Pihlström \\ Helsinki Collegium for Advanced Studies \& Faculty of Theology, University of Helsinki, Finland \\ E-mail: sami.pihlstrom@helsinki.fi
}

\section{Introduction: the encounter between pragmatism and logical empiricism}

The Americanization of originally European analytic philosophy, beginning with the rise of Nazism in Europe before WWII, has aptly been described as a move "from the Vienna Circle to Harvard Square" (Holton 1993). There are, indeed, significant links between the Viennese-based (and more generally European) logical empiricism ${ }^{1}$ and the American tradition of pragmatism; these links, furthermore, can also be argued to have been influential, albeit often implicitly, in the emergence of what is today known as "neopragmatism". ${ }^{2}$ In the United States, C.I. Lewis, Ernest Nagel, and W.V. Quine, among others, were important mediators between these philosophical schools; accordingly, the Columbia and Harvard philosophy departments were instrumental in the development of this very special dialogue between two key orientations of twentieth century philosophy. ${ }^{3}$ Another mediating figure - some decades earlier - between pragmatism and early analytic philosophy was Frank Ramsey, who could have changed the history of twentieth century philosophy by developing a synthesis of these philosophies, had he lived longer. ${ }^{4}$ Charles Morris's "pragmatic empiricism" was yet another milestone between Vienna and America; Morris argued for the complementarity and even convergence of pragmatism and logical empiricism throughout the 1930s, and he returned to the topic in his contribution to the Library

\footnotetext{
${ }^{1}$ I will speak of "logical empiricism" instead of "logical positivism", unless there is some philosophical or historical reason to be more specific about the terminology. By "logical empiricism" I understand the somewhat broader set of ideas and the slightly more inclusive philosophical approach that survived the collapse of the Vienna Circle (and thus the collapse of logical positivism in a strict sense). The Finnish philosopher Eino Kaila may in fact have been the first to coin the term, "logical empiricism" (der logische Empirismus). Unlike some others associated with the Vienna Circle, he was careful to call his view "logical empiricism", never "logical positivism".

${ }^{2}$ For the distinction between "neopragmatism" and "new pragmatism" (which need not have any explicit relation to the historical tradition of pragmatism), see Misak (2007).

${ }^{3}$ For a recent study on Lewis and the "pragmatic a priori", see Järvilehto (2011); for detailed examinations of the concept of the a priori in logical empiricism, see Friedman (2007) and Mormann (2012). For discussions of Quine's problematic place in the pragmatist tradition, see Koskinen and Pihlström (2006) and Sinclair (2013). In this paper, because of my focus on neopragmatism, I will have to mostly ignore both Lewis and Quine. By no means can I hope to aim at any kind of exhaustiveness in my treatment of pragmatism and logical empiricism; I will merely be able to offer some perspectives on the matter, informed by the development of neopragmatism.

${ }^{4}$ For instance, Ramsey's 1927 essay, "Facts and Propositions", articulates a pragmatic understanding of the meaning of a proposition in terms of the conduct that would result from asserting the proposition. This is, clearly, a position reminiscent of Charles Peirce's and William James's views.
} 
of Living Philosophers volume on Rudolf Carnap in the 1960s (see Morris 1937, 1938, 1963; cf. Carnap 1963). But the dialogue between pragmatism and logical empiricism was not restricted to the work of such bridge-builders as Morris and Nagel who have later become somewhat marginalized. Even the giants of the two movements themselves entered into a fruitful dialogue in the early 1930s. The mutual visits across the Atlantic in the beginning of the 1930s and the preparations for the 1934 International Congress for Philosophy in Prague (see Limbeck-Lilineau 2012), as well as Carnap's and John Dewey's exchange of views on meaning and the nature of philosophical problems in Philosophy of Science in 1934 are examples of this (cf. Shook 1998, 462), as is Hans Reichenbach's (1939) criticism of Dewey's instrumentalist philosophy of science from the point of view of what he regarded as a more realistic understanding of science. In the late 1930s, Dewey also contributed to the International Encyclopedia of Unified Science, a project launched by the Vienna Circle philosophers. ${ }^{5}$

Leading scholars of the history of logical empiricism, such as Thomas Uebel (1992, 1996, 2007) and Alan Richardson (1998), have investigated the relations between logical empiricism and twentieth century naturalism and pragmatism in great detail, drawing attention, for instance, to how "Quinean" - that is, naturalistic and anti-foundationalist - some of Otto Neurath's views were already decades before the emergence of Quine's philosophy (see also Richardson and Uebel 2007). As Richard Creath (2007, 335) points out, Quine's caricature of Carnap's conventionalism - as something allegedly entirely different from the more pragmatic naturalism Quine himself advanced - has unfortunately been "endlessly repeated by others". Gradually this picture has become more nuanced, to the extent that it is almost a commonplace today to appreciate the many common ideas shared not only by Quine and Carnap but generally by pragmatism and logical empiricism. Therefore, as Cheryl Misak (2013, chapter 9) also argues, the thesis that pragmatism, which had flourished in the United States from William James's popular philosophy in the early 1900s until Dewey's late work between the world wars, was "eclipsed" by logical empiricism (and later by analytic philosophy) is problematic, if not outright mistaken. Not only does the pragmatic maxim, which urges us to examine the meaning of our concepts in terms of the potential practical consequences of their objects, ${ }^{6}$ resemble the logical empiricists' verificationist theory of meaning, according to which the meaning of a sentence is reducible to its method of verification (and only empirically verifiable sentences are meaningful);

\footnotetext{
${ }^{5}$ For more details and exact references (including archival documentation based on Carnap's, Schlick's, Neurath's and others' papers and correspondence), see Limbeck-Lilineau (2012). For Dewey's Encyclopedia contributions, see his (1938) and (1939). Already some years later Dewey was, however, critical of the project and his own involvement in it. For an examination of Dewey's criticism, see da Cunha (2012).

${ }^{6}$ On the pragmatic maxim and its different versions and applications, see, e.g., Pihlström (ed.) (2011), and Burke (2013).
} 
also the resolute rejection of unempirical metaphysical speculation, as well as the link between scientific progress and social progress, can be regarded as points of contact between the two traditions. Clearly both the pragmatists and the logical empiricists, at least after the Vienna Circle philosophers' arrival in the United States, understood this. As Misak concludes: “The similarities between pragmatism and logical empiricism were there (and where recognized) from the beginning." (Ibid., 175.)

Furthermore, there seems to be a growing consensus about the fact that it was the internal self-critical development - rather than any external pressure - of logical empiricism, especially following key Vienna Circle members' emigration from Europe in the 1930s, that led to positions relatively close to the naturalistic, fallibilistic pragmatism that had been developed by Dewey, Nagel, Lewis, and Morris. Hence, the explicit contacts between the two traditions that were established in the 1930s may not have played any crucial role in this rapprochement. ${ }^{7}$ The Vienna Circle thinkers might have arrived at their somewhat more relaxed stance - in comparison to the strict verificationism many of them had advocated in the 1920s and early 1930s - even if they had never directly encountered Dewey and the other pragmatists.

Given this state-of-the-art in the scholarship on the history of pragmatism and logical empiricism, there is little I can add to the historical picture of this dialogue; I hope, however, to provide a distinctive perspective on the topic by taking seriously not just the relations between logical empiricism and pragmatism but especially between these two and neopragmatism, ${ }^{8}$ as well as Ludwig Wittgenstein's relevance to both pragmatism and neopragmatism. My focus will, then, be on the philosophical background of neopragmatism rather than on the pragmatist tradition as a whole (or logical empiricism as such, for that matter). My investigation is not intended to throw much new historical light on logical empiricism and its relations to pragmatism, but I do hope that it will philosophically illuminate the ways in which neopragmatism grows out of the pragmatism - logical empiricism dialogue. I will not consider the above-mentioned mediators (e.g., Nagel, Lewis, or Morris) in any detail; my main focus in the early sections of the paper will be on the leading neopragmatist Hilary Putnam's "residual Carnapianism" (as I will call it) as well as on some related themes in Wittgenstein scholarship that may be open to pragmatist reconsideration.

\footnotetext{
7 See especially Limbeck-Lilineau (2012). The international philosophy congress in Prague in 1934 was a crucial step in the emergence of the mutual recognition of pragmatism and logical empiricism, but as Limbeck-Lilineau concludes, "neither the [logical empiricists'] liberalization of the meaning criterion, nor the introduction of dispositional concepts was initiated through the contact with pragmatism" (107).

${ }^{8}$ In fact Charles Morris used the term "neopragmatism" already in 1928. (I owe this piece of information to Christoph Limbeck-Lilineau.) According to him, pragmatism was already then, before its explicit encounters with logical empiricism, living a second phase, after the early phase of Peirce's and James's works.
} 
I will, in particular, critically discuss the status of metaphysics in pragmatism and neopragmatism. This is an important theme in contemporary pragmatism scholarship not only because of its intrinsic interest but also because metaphysics has forcefully returned to the center of mainstream analytic philosophy, and pragmatists need to reflect on their ways of reacting to such developments. While metaphysics may not seem to survive Putnam's broadly Carnapian criticisms of metaphysical realism, Putnam's own account of “objectivity without objects” (to be revisited below) can be applied to, for instance, metaphysical topics that no lesser a figure than Immanuel Kant found absolutely central to the very pursuit of metaphysics (viz., the soul, freedom, and God) - instead of being applicable only to the issues in, say, the philosophy of mathematics and ethics to which Putnam himself applies the idea. Indeed, it can be shown that while neopragmatism has successfully moved beyond several logical-empiricist doctrines, such as the dichotomies between the analytic and synthetic as well as between fact and value (not to forget neopragmatists' general rejection of the scientism we often associate with logical empiricism), neopragmatism still remains committed to other important logical-empiricist ideas, especially the critique of metaphysics. This is still rather clearly manifested, e.g., in Putnam's Carnapian-like rejection of metaphysical realism as well as his reluctance to formulate his views on the fact-value entanglement in metaphysical terms (cf., e.g., Pihlström 2010).?

After the sections on Putnam and Carnap, I will show how Morton White's another somewhat neglected philosopher integrating logical empiricism with pragmatism - bolistic pragmatism can help us in adopting a truly pragmatist approach to metaphysics (though it also has its residual elements of logical empiricism). In particular, White's holistic pragmatism crucially contributes to developing an overall view capable of integrating metaphysical and antimetaphysical ideas and beliefs, just like it enables us to regard factual and normative beliefs as empirically testable within the same holistic totality. In a sense, then, holistic pragmatism points to a way to move on from the dialogue between logical empiricism and (neo)pragmatism - or so I will argue.

\section{Linguistic frameworks and conceptual relativity: Carnap and Putnam}

Let us turn more closely to the encounter pragmatism had with logical empiricism by recapitulating some familiar points about Carnap's doctrine of linguistic frameworks. This

\footnotetext{
${ }^{9}$ Richard Rorty's - another key neopragmatist's - more "postmodern" critique of metaphysics is, of course, very different from the logical empiricists' (and from Putnam's), but he shares with Carnap et al. the conviction that in some sense metaphysics fails to make sense.
} 
discussion will illuminate the role of logical empiricism as a source of insights for neopragmatism especially because of the inspiration Putnam drew from logical empiricism, most notably his greatest teachers Carnap and Reichenbach. Even though Putnam mostly worked with Carnap on inductive logic instead of, say, the realism issue, this background is rather obvious when we consider the striking similarity between Putnam's (1981, 1990) “internal realism" (his basic position in the 1980s) and Carnap's (1950) theory of linguistic frameworks and internal vs. external questions of existence. ${ }^{10}$

Putnam's late collection of essays, Philosophy in an Age of Science (2012), contains his most recent substantial attempts to deal with his relation to his logical empiricist teachers, especially in relation to the realism issue. That book in fact makes it clear that he has continued to struggle with his logical empiricist heritage until this day; therefore, it is worth examining here. In particular, Putnam's desire to avoid metaphysics - when developing pragmatism, when developing his theory of the fact-value entanglement, in the philosophy of religion, and in other contexts - can still be seen as a remnant of logical empiricism. The new book demonstrates that Putnam, although he has now turned (back) to a form of metaphysical realism and abandoned his former internal realism, continues to defend what he already in the 1980s called conceptual relativity. This idea was the core of his internal or pragmatic realism: there is no single privileged way the world is, no definite set of objects the world consists of, no fundamental "God's-Eye View" on reality, but a plurality of possible conceptualizations of the world - that is, a plurality of linguistic frameworks we can use to categorize reality and to identify objects whose existence we are committed to. Hence, arguably, Putnam still joins Carnap at a very basic level, though rejecting many of Carnap's more detailed views, such as the "methodological solipsism" of the 1928 Aufbau (Carnap 1967). Let us therefore explore some continuities and discontinuities between Putnam's views in the early 1980s (that is, the peak of his internal realism) and today (that is, in his 2012 volume collecting his recent work on realism and other topics). ${ }^{11}$

\footnotetext{
${ }^{10}$ Among Putnam's many critics, Kenneth Westphal (2003) is particularly explicit in his criticism of this residual Carnapian element in Putnam's internal realist position. Putnam, of course, is not the only neopragmatist whose Carnapian or quasi-Carnapian ideas would be worth examining. For example, if we broaden our concept of neopragmatism to include Thomas Kuhn's (1970) and other post-positivist thinkers" "new philosophy of science" just think of Kuhn's account of the practice-embeddedness of normal-scientific research within a paradigm - we may certainly appreciate the analogy between the Kuhnian paradigm and the Carnapian linguistic framework. Such analogies have been suggested by Friedman (e.g., 2001, 2003). Richardson (2007, 356) also notes that paradigms and linguistic frameworks play analogous roles as "conditions of scientific knowledge". See further Pihlström and Siitonen (2005) and Pihlström (2008) and (2012b). In this essay, I will largely have to set aside the Kantian dimensions of pragmatism, even though that topic is also clearly relevant to the reappraisal of neopragmatism in relation to logical empiricism (cf. also Pihlström 2003 and (ed.) 2011).

${ }^{11}$ I cannot here even summarize Putnam's opposition between metaphysical and internal realism in the way it was elaborated in his famous writings in the 1980s and early 1990s; I hope this material is relatively familiar to my readers, as this complex philosophical debate largely shaped the discussion of realism for decades. For more details, see, e.g., Pihlström (1996) and (1998), as well as (with later reflections) (2009). My focusing on Putnam's 2012 book
} 
While Putnam's internal realism was often regarded as a form of realism just by name and was in fact seen as involving a strong commitment to anti-realism, especially due to Putnam's flirtation with the kind of semantic anti-realism and verificationism defended by Michael Dummett (and, of course, already by the logical empiricists), Putnam himself insisted early on - and continues to insist - that what he called, and still calls, conceptual relativity is "fully compatible with realism in metaphysics" (Putnam 2012, 56; see also 101-102). Hence, it is possible to be a realist even if one follows Putnam in maintaining that there is no fundamental metaphysical fact of the matter as to whether, say, mereological sums ought to be included in our ontology of the small "Carnapian world" of three individuals (x1, x2, x3). ${ }^{12}$ A version of this kind of conceptual relativity can be found already in classical pragmatism, especially in James's pragmatic pluralism (e.g., James 1907, chapter 6; see also Pihlström 2008, 2013). ${ }^{13}$ While James does not operate with linguistic frameworks - he was, after all, a pre-linguistic-turn philosopher - his views on the relativity of objects to humanly constructed perspectives guided by human needs and interests is clearly a precursor of both the Carnapian linguistification of ontology and the Putnamian doctrine of conceptual relativity.

Paying due attention to Putnam's Carnapian ideas, we may ask when neopragmatism emerged. (I am not concerned with the term "neopragmatism" but with the emergence of some of the distinctive ideas we associate with it.) There is no trivial answer. Presumably it emerged only in the 1980s when Putnam was busily defending internal realism and noted its connection with pragmatism (and even pointed out, in his 1987 volume The Many Faces of Realism and elsewhere, that he should have called internal realism "pragmatic realism")? Or perhaps, rather, it emerged in 1979 when Richard Rorty published Philosopby and the Mirror of Nature and shocked his analytic readers by regarding Dewey as one of the most important thinkers of the twentieth century? ${ }^{14}$ Or already in 1951 when Quine in “Two Dogmas of Empiricism” exclaimed that our ontological

\footnotetext{
here is also motivated by the fact that he there says various new things about his relation to metaphysics that seem to play an important role in the development of his views on realism.

12 Putnam discusses this example in many places, including Putnam (1987), (1990), and (2004). See also Pihlström (1996). It would require a long story to explain how this conceptual relativity differs from Quine's (1969) "ontological relativity", according to which ontology is relative to theory or translation. No interpretation of Quine can be offered in this essay, so I must skip that exercise here. On Putnam's criticism of Quine, see, e.g., Putnam (1994) and Koskinen and Pihlström (2006).

${ }_{13}$ Putnam, however, distinguishes between conceptual relativity, which involves equivalent or mutually intertranslatable conceptual schemes, and the more general phenomenon of conceptual pluralism, which has no such involvement but recognizes that "the world has many levels of form" irreducible to each other or to any single privileged form. See, e.g., Putnam (2012), 64-65. Another point of comparison here would be Goodman's (1978) controversial theory of "worldmaking", which postulates a plurality of "world versions" (see also Pihlström 1998, chapter 1).

${ }^{14}$ In addition to Quine, Rorty is another major philosopher that must be more or less neglected in this essay. See Pihlström (1996) and (1998) for my (already somewhat dated) critical explorations of Rorty's neopragmatism. For critical comparisons of Putnam's and Rorty's views on realism, truth, and religion, see Pihlström (2004) and (2013), chapter 3 .
} 
postulations are, "where rational, pragmatic", and claimed to represent a "more thorough pragmatism" than Carnap? ${ }^{15}$

There is hardly any philosophical or historical need to agree about the exact timing of the birth of neopragmatism. One possible answer, however, is that neopragmatism emerged already in 1934 (avant la lettre) when Carnap formulated his famous Toleranaprinzip in Logische Syntax der Sprache. ${ }^{16}$ According to this principle of tolerance, "there is no morality in logic": "In der Logik gibt es keine Moral. Jeder mag seine Logik, d.h. seine Sprachform, aufbauen wie er will. Nur muss er, wenn er mit uns diskutieren will, deutlich angeben, wie er es machen will, synktaktische Bestimmungen geben anstatt philosophischer Erörterungen.” (Carnap 1934, 45.) We can, then, freely choose our language, provided that we offer syntactic rules and definitions for its expressions. Later Carnap turned more to semantics, modifying his earlier very restrictive conception of philosophy as the logical syntax of science, but the fundamental idea of tolerating different linguistic frameworks serving different purposes survived the changes in the details of his position. This basic view was, as is well known, elaborated by Carnap in his 1950 essay, "Semantics, Empiricism, and Ontology" - famously criticized by Quine in "Two Dogmas" - but the idea of a plurality of languages through which we categorize reality was there already in 1934. In a sense it was at work already in 1928 in Der logische Aufbau der Welt, in which Carnap had suggested that both phenomenalist and physicalist - that is, autopsychological and heteropsychological (or eigenpsychische and fremdpsychische) - starting points for the construction of scientific language (and, hence, for the "logical construction of the world") are possible, though the phenomenalist one should be preferred (see Carnap 1967; cf. Richardson 1998).

It is in fact easy to characterize Carnap's position as a form of "neopragmatism" by using the terminology he adopts in the 1950 paper. There Carnap distinguishes between "internal" existence questions that are posed within a linguistic framework, concerning the existence of certain entities within that framework, and "external" ones, which concern the adoption of the framework itself. (See Carnap 1950, 209-210.) The external questions lack theoretical significance; only internal questions can be answered by means of empirical, scientific research. External questions are resolved only practically; choosing one linguistic framework instead of another is a matter of effectiveness, fruitfulness, and simplicity, among other things not an empirical or theoretical matter (ibid., 210-212, 219). In particular, the problem of the

\footnotetext{
15 "Two Dogmas" is available in Quine (1953a); for the famous "more thorough pragmatism" quote, see 46. An examination of Quine's and Carnap's complex relation would obviously be beyond the scope of this article. For their correspondence, see Creath (1990). See also, for useful examinations of Quine's relation to Carnap, Neurath, and other leading logical empiricists, Isaacson (2004, especially 229-249), as well as Creath (2007).

${ }^{16}$ Or perhaps we could say that it emerged already in 1928 when Morris used the term (cf. above).
} 
reality of the "world of things" is, metaphysically understood, a mere pseudo-problem (just like Carnap had already argued in the Aufbau and other early works):

To be real in the scientific sense means to be an element of the framework; hence this concept cannot be meaningfully applied to the framework itself. Those who raise the question of the reality of the thing world itself have perhaps in mind not a theoretical question as their formulation seems to suggest, but rather a practical question, a matter of a practical decision concerning the structure of our language. We have to make the choice whether or not to accept and use the forms of expression for the framework in question. (Ibid., 210-211.)

As in 1934, Carnap in 1950 maintains a tolerant view on the plurality of linguistic frameworks. We should, he tells us, "grant to those who work in any special field of investigation the freedom to use any form of expression which seems useful to them", as the work in that field "will sooner or later lead to the elimination of those forms which have no useful function" (ibid., 228). The paper concludes with a famous rule: "Let us be cautious in making assertions and critical in examining them, but tolerant in permitting linguistic forms." (Ibid.)

This is essentially the view that Putnam rediscovered and defended in the 1980s when arguing that the world possesses no "ready-made" ontological structure of its own but can be "sliced up" differently by using different conceptual schemes or frameworks - and to which he still, after having returned to metaphysical realism, at least to some extent adheres. It does not seem to me that Putnam's criticisms of, for instance, Carnap's methodological solipsism (as expressed in the Aufbau) have in any essential way departed from the basic idea of there being a plurality of linguistic frameworks - or conceptual schemes, perspectives, traditions, paradigms (you name it) - through which we language-users categorize reality, frameworks whose critical comparison is a pragmatic matter undecidable by empirical and/or theoretical grounds. Moreover, the attempt to arrive at an empirical or theoretical answer to an external question of existence in an absolute sense, say, to the question whether there "really" are such things as numbers or tables, verges on meaninglessness. ${ }^{17}$

In this sense Putnam, even today, to some extent still remains a Carnapian - even after his realism has become considerably stronger as a result of his rejection of internal realism

\footnotetext{
17 Putnam (1995, 69-73) does contrast Carnap's methodologically solipsist and verificationist empiricism to the classical pragmatists' cooperative and interactionist view of inquiry; this kind of criticism of Carnap's "spectator" conception of observation is continued, e.g., by Burke (2013, 68-72). This does not remove Putnam's and Carnap's fundamental agreement regarding realism, conceptual relativity, and metaphysics, however.
} 
and its epistemic theory of truth that, arguably, was practically indistinguishable from the logical empiricists' verificationism. ${ }^{18}$ It is undeniable that Quine's (1969) later ontological relativity, which gave up the Carnapian distinction between internal and external existence questions, also crucially shaped Putnam's approach to the realism issue. According to Quine and (perhaps) also Putnam, all existence questions have a pragmatic dimension; thus, the division between internal and external questions collapses together with the analytic/synthetic distinction. Yet, Putnam's many criticisms of Quine make it clear that he never followed Quine's attack on Carnap to the very end, that is, to the final repudiation of the key Carnapian distinction - even though he does seem to agree with Quine (and Wittgenstein) rather than Carnap when saying that "[w]hat Carnap is trying to do in 'Semantics, Empiricism and Ontology,' it would seem to both Quine and Wittgenstein, is to find an external standpoint from which to condemn external questions as meaningless" (Putnam 2012, 345). Thus, while Quine (who has often been described as the "killer" of logical positivism) remained, according to Putnam, "the greatest logical positivist" (see Putnam 1990), we may say that Putnam himself remains faithful to some of the fundamental principles of logical empiricism until this day.

Even though Putnam does not strictly speaking subscribe to Carnapian criteria of meaning or to the view that external questions of existence are literally meaningless, it is, I believe, legitimate to conclude that whenever Putnam defends a position close to, say, James's or Dewey's pragmatism (or pragmatic pluralism), he does this, as we may say, in (and not despite) his Carnapian mode. His relatively few remarks on James's and Dewey's views on science also presuppose the more recent discussions of scientific realism and its empiricist alternatives that were not available to the pragmatist classics themselves; hence, even those remarks presuppose the context of logical empiricism. ${ }^{19}$ Neopragmatism more generally - at least Putnam's and Rorty's - is primarily a language-oriented form of pragmatism in contrast to the more experience-based classical pragmatism (cf. Hildebrand 2003). All of this also indicates how strongly "Carnapian" (rather than, say, "Deweyan”) Putnam's neopragmatist position on realism vs. antirealism is. ${ }^{20}$

\footnotetext{
18 One might perhaps apply the pragmatic maxim to find out what, if any, the key difference between Vienna Circle verificationism and Putnam's 1980s Harvard verificationism was. These might come up as practically identical positions.

${ }^{19}$ For instance, I am not quite sure if it is appropriate to call James and Dewey "fictionalists" about theoretical entities (Putnam 2012, 93). For a discussion of the pragmatist tradition from the point of view of the question of scientific realism, see Pihlström (2008).

${ }^{20}$ In addition to Putnam, Huw Price (2011) is another neopragmatist developing partly Carnapian views even today, defending a Carnapian pluralism of linguistic frameworks. He compares Carnap's (1950) pluralism about ontological commitment to what would today be called "global irrealism" (Price 2011, 284) and contrasts Carnapian pluralism with Quinean monism, reminding us that a pragmatic or functional pluralism provides motivation for Carnap's logico-syntactical pluralism (ibid., 289). Quine's objections to Carnap can, according to Price, be to a large extent defused when we note that the one and the same existential quantifier can be "employed in the service of different
} 
However, we can, and should also take seriously the Kantian elements of Putnamian (neo-)pragmatism, and derivatively of logical empiricism, even though this cannot be done in the present paper in any detail. It would - as I have suggested elsewhere (e.g., Pihlström 2009) - be perfectly possible for Putnam to admit that our ontologies are humanly constructed in a transcendental sense while the objects and processes of the world we postulate within such ontological theorizing remain empirically (and, hence, factually, causally, and otherwise) independent of us and our theories. Thus, empirical ontological commitments internal to our frameworks have, and need, an extra-human standard (viz., the way things are, when seen through that framework), while the adoption of the framework itself is a kind of transcendental constitutive activity only pragmatically decidable - or criticizable. This idea, when further developed, would come close to C.I. Lewis's (1923) "pragmatic a priori”. Kantian apriorism, and particularly transcendental idealism, however, are not anything that Putnam would ever be willing to embrace. Putnam has pointed out repeatedly that we should not confuse "making up" our notions with "making up" real systems in the world, unless we want to "slide into idealism", which is "a bad thing to slide into" (Putnam 2012, 64). Now, of course this is itself a Carnapian distinction, echoing the external vs. internal contrast all over again. ${ }^{21}$ It is, arguably, a distinction that the classical pragmatists already cast a critical eye on while preserving (in my view) it in a pragmatic form. Something like the transcendental vs. empirical distinction must be made in order for Putnam's own realism-with-conceptual-relativity to succeed. ${ }^{22}$

Here, various philosophers' work on the pragmatically relativized a priori - from Lewis to Michael Friedman et al. - is highly relevant to the emergence of neopragmatism. Similarly, the discussions by classical pragmatists themselves, Dewey in particular, concerning the independence vs. dependence of the objects of inquiry from processes of inquiry are reinterpretable along these transcendental lines (cf. Pihlström 2008). We might say that the objects of scientific inquiry are, at least generally, empirically independent of inquiry and inquirers while being transcendentally dependent on inquiry because transcendentally constituted

functional, pragmatic or linguistic ends" (ibid., 291) - which, in effect, is what Putnam has argued when claiming that words like "exist" or "there is" have a plurality of different uses (e.g., in Putnam 2004). Indeed, Price (2011, 292, n8) perceptively points out that his "Carnapian view" comes close to Putnam's “pragmatic pluralism”. While Price's historical comments on Carnap vs. Quine (vs. Putnam) are in my view appropriate, I do not think we need to follow him into the final conclusion that "metaphysics remains where Carnap left it" (ibid., 303), nor to his proposal to integrate pragmatic functional pluralism and metaphysical "deflationism" (ibid.). This is because there is another more Kantian - strategy for revising (and reviving) pragmatist metaphysics (cf. Pihlström 2009), though that, of course, is an entirely different story not to be told here.

${ }^{21}$ Kant $(1781 / 1787)$ himself would not recommend confusing the two, either, because the things in themselves, in his view, clearly are not "made up".

22 A similar claim could be made about Philip Kitcher's (2013) admirable proposal - which comes close to Putnam's recent views - to integrate realism (especially scientific realism) with pragmatic pluralism and the interest-relativity of our world-categorization (see especially Kitcher on "Carnap and the Caterpillar" in ibid., chapter 8). The in my view essential transcendental dimension is missing from the otherwise very balanced and carefully worked-out position. 
through the processes of inquiry (along with the construction of relevant linguistic frameworks and/or conceptual schemes, to put it in more logical-empiricst terms). Putnam, however, would presumably regard this way of speaking as "bad" idealism.

More generally, Putnam's anti-metaphysical (indeed, logical-empiricist) background manifests itself, for instance, in his reluctance to accept any genuine metaphysics of values indeed, his account of the fact-value entanglement (see Putnam 2002, 2004) seems to be purely linguistic or conceptual, partly epistemic but certainly non-metaphysical - as well as in his resolutely non-metaphysical philosophy of religion indebted to the Wittgensteinian tradition in that field. ${ }^{23}$ This is what Putnam's Carnapianism comes down to: a deep-seated avoidance or even fear of metaphysics - even in areas like ethics and religion where he clearly has already moved very far away from Carnap's and most logical empiricists' views. Even if pragmatically needed, metaphysics is to be avoided. Curiously, Putnam's Carnapian anti-metaphysics and Levinasian "post-onto-theological" approach to moral value (cf. Putnam 2004) join hands in his campaign for "ethics without ontology". Putnam does not, then, seem to be sufficiently receptive to the pragmatist idea (arguably at work in William James, among others) that metaphysics should not be a priori dismissed but should itself be pragmatically elaborated and examined; its true practice-involving core ought to be traced out by employing the pragmatic maxim in an ethically engaging way (as suggested in Pihlström 2009).

\section{Pragmatist and neopragmatist (anti-)metaphysics}

Why are Putnam's twists and turns regarding realism and metaphysics interesting and important? The reason I have invoked Putnam (in relation to Carnap) here is that this specific case may tell us something more general about the ways in which pragmatism and neopragmatism have reacted to the question concerning the status of metaphysics within philosophy - a question that logical empiricism, of course, focused on as well. These issues are at the center of any inquiry into the relations between pragmatism and logical empiricism.

Logical empiricism generally, of course, was a strongly anti-metaphysical movement. In A.J. Ayer's memorable phrase, "no statement which refers to a 'reality' transcending the limits of all possible sense-experience can possibly have any literal significance" (Ayer 1936, 46). Philosophy must be sharply distinguished from age-old metaphysical speculation (ibid., 55 ff.);

\footnotetext{
${ }^{23}$ See Pihlström (2013) for some reflections on neopragmatist philosophy of religion, including Putnam's. Note that Putnam nowhere seems to comment on the classical pragmatists' relations to the Vienna Circle and logical empiricism, except for what he says in his 1995 volume on Wittgenstein as a kind of pragmatist.
} 
metaphysics can only have poetic, aesthetic, moral, emotive, or expressive value - instead of any cognitive value (ibid., 59-61). In particular, Ayer argues that the problem of realism vs. idealism, metaphysically construed, is "fictitious", devoid of any cognitive or theoretical content (ibid., 5455, 182-193). In a similar vein, Moritz Schlick, the leading Vienna Circle figure, rejected the realism issue as meaningless metaphysics: “The denial of the existence of a transcendent external world would be just as much a metaphysical proposition as its assertion; the consistent empiricist does not therefore deny the transcendent, but declares both its denial and its affirmation to be equally devoid of meaning." (Schlick 1932-33, 54.) And we can easily find a host of similar statements from Carnap's writings - and, by extension, even from Putnam's.

We already noted that one clear indication of Putnam's logical-empiricist background influences is the desire to avoid any commitment to metaphysics, epitomized in his "residual Carnapianism" regarding internal and external questions. ${ }^{24}$ However, one of the challenges for pragmatism today, in its dialogue with other philosophical approaches, is to contribute in its own specific ways to the kind of discussions emerging within "analytic metaphysics". Despite the strongly anti-metaphysical beginnings of what is today known as analytic philosophy, contemporary analytic philosophy is not only tolerant of but even largely dominated by metaphysics. A viable form of pragmatism today can hardly avoid taking such metaphysical approaches into account. Not all metaphysical theorizing is sheer unempirical speculation. On the other hand, in seeking legitimate forms of metaphysics, or inquiring into the possibility of metaphysics in contemporary philosophy, we do need to take seriously the kind of criticism of metaphysics that both logical empiricism and pragmatism engaged in. This leads to a tension between metaphysics and the criticism of (or even rejection of) metaphysics in contemporary neopragmatist philosophy. ${ }^{25}$

Let me briefly illustrate this neopragmatist tension between metaphysics and antimetaphysics by drawing attention to a notion we may call, using Putnamian language, "objectivity without objects". An example drawn from "special metaphysics" (rather than

\footnotetext{
${ }^{24}$ However, we must be careful here. When Putnam (2012, 487-488) tells us that he "cannot inhabit the intellectual world" of philosophers like Hegel, Spinoza, or Leibniz, he does not mean that such philosophers wrote meaningless sentences; to suggest that they just wrote "nonsense" is "a hangover from the mistaken idea that we should "just say no' to metaphysics" (ibid., 488). Cf. also the above-quoted passage in which Putnam says one can be a realist "in metaphysics" while accepting conceptual relativity (ibid., 56). So Putnam's rejection of metaphysics is not total; he has, better than some others, recovered from the logical empiricist "hangover". However, pace Putnam, I would suggest that one can find certain views unintelligible (cf. ibid., 490), or some intellectual worlds inhabitable, as a result of transcendental reflection on human capacities and incapacities, specifically as manifested in one's own case. Such reflection may, for instance, lead us to a deeper understanding of why one, when faced with, say, an eliminativist physicalist position, “[hasn't] got these thoughts or anything that hangs together with them" (Putnam, ibid., quoting Wittgenstein's Lectures and Conversations on Aesthetics, Psychology and Religious Belief, a work he finds important in his writings on religion as well).

${ }^{25}$ Cf. Pihlström (2009) and (2013). For a richer array of investigations of the fate of metaphysics today, see Haaparanta and Koskinen (2012).
} 
"general metaphysics") may help us in cashing out the pragmatic yet metaphysical relevance of this idea. This is of course only one possible way in which metaphysics could be "saved" in pragmatism.

As I have suggested on earlier occasions, when developing a (Jamesian) pragmatist account of metaphysics, especially the famous Kantian metaphysical "transcendental ideas" that for Kant constitute the proper subject matter of metaphysics, viz., God, freedom, and the soul as a pragmatically reinterpreted version of what Kant in the Second Critique called the "postulates of practical reason" ${ }^{26}$ - we arguably may make a pragmatically legitimate commitment, from within our practices themselves (especially ethical practices), to a certain kind of reinterpreted transcendence. We employ these "transcendental ideas" in a certain objectively normative and guiding role. The legitimacy or, perhaps, moral necessity of such a commitment might even be defended by means of a kind of practice-involving, hence "naturalized", transcendental argument: as James argued - though, of course, not explicitly transcendentally - it might be necessary for an individual to embrace a metaphysical postulation of theism, if s/he seeks to maintain a "morally strenuous" mood in life. ${ }^{27}$ However, we cannot employ this account of theistic metaphysics and its legitimacy to develop a theory of any theological objects, because in the Kantian context only properly transcendental conditions, such as the categories of the understanding (e.g., causality) and the forms of pure intuition (space and time), are necessary conditions for the possibility of the objects of experience in the sense that all empirical objects must conform to them; transcendent and/or theological ideas, such as the metaphysically pregnant ideas of God, freedom, and the immortal soul, do not play such an objectifying and experience-enabling role, even if they can be argued to play a transcendental role as enablers of full moral commitment. More precisely, while the categories, in Kant, can be regarded as normative requirements of objecthood, this cannot be said about the postulates of practical reason, even if their status is also based on a transcendental argument.

Hence, even though there can be a certain kind of pragmatic objectivity in ethics, metaphysics, and theology based on the demands of our practices - or so my (real or imagined) Jamesian pragmatist would argue - there cannot be any theological objectivity in the sense of any legitimate rational postulation of theological objects, understood as an analogy to the postulation of, say, theoretical objects in science serving the purpose of explaining observable phenomena. Now, we may see this (Jamesian) pragmatist understanding of theological objectivity, analogous

\footnotetext{
${ }^{26}$ I propose this Kantian-like re-reading of James in Pihlström (2013) and in a preliminary way already in Pihlström (2009), chapter 7; the details must be skipped here. No reading of Kant can, for obvious reasons, be provided here. 27 On James's pragmatist philosophy of religion and the relation between ethical and metaphysical standpoints, see, in addition to Pihlström (2013, chapter 4), also Rydenfelt and Pihlström (2013).
} 
to the Kantian postulates, as a version (or extension) of what Putnam (2002, 2004) calls "objectivity without objects". The examples Putnam himself provides primarily come from mathematics and ethics. We can, and should, understand the objectivity of these quite different practices - and the related fact-value entanglement in ethics - as not requiring the postulation of any mysterious transcendent objects out there, whether mathematical (numbers, functions) or ethical (values, moral facts). As Putnam has argued for a long time, there is no need to think of moral objectivity as needing any ontological commitments to "queer" objects, contra "error theorists" like J.L. Mackie (1977) (see Putnam 1981, 1990; cf. Pihlström 2005). We should now, I submit, understand whatever "moral objectivity", or "theological objectivity", there is available to the pragmatist along similar lines. The relevant kind of objectivity lies in our practices of engagement and commitment themselves, in our habits of action embodying certain ways of thinking about ourselves and the world in terms of transcendence-involving notions such as God, freedom, and the soul. ${ }^{28}$

This conception of pragmatic objectivity in metaphysics and theology (and, analogously, in ethics) is compatible not only with certain views on religion as a practice or form of life derived from the later Wittgenstein's writings, but also with a transcendental position we find in the early Wittgenstein: God does not appear in the world; immortality is timelessness, or life in the present moment, instead of any infinite extension of temporal existence; and my will cannot change the facts of the world but "steps into the world" from the outside (see Wittgenstein 1921, JS 6.5ff.). Accordingly, God is not an object of any kind, nothing - no thing whatsoever - that could "appear in the world". Nor can the subject's freedom or possible (Kantian-like) immortality be conceptualized along such objectifying lines. The subject that philosophy deals with - the metaphysical or transcendental subject - is a "limit" of the world rather than any object in the world (ibid., \5.64).

It is from these remarks that the early Wittgenstein's peculiar form of solipsism emerges. In a sense, for the solipsistic subject of the Tractatus, all the objects in the world are

\footnotetext{
${ }^{28}$ In addition to the realism issue, Putnam's philosophy of religion is worth briefly taking up here because of its strong Wittgensteinian influences. Going back to the Viennese background of Wittgenstein (in the sense of Janik and Toulmin 1973) instead of the Vienna Circle proper is therefore the crucial move at this point. While neither Putnam nor other neopragmatists have shared the Vienna Circle's condemnation of the entire theism vs. atheism debate as a piece of speculative metaphysics - recall that Carnap, among others, regarded both theism and atheism as equally meaningless metaphysics - Putnam's pragmatist attitude to religion can again be reconnected with his Carnapian, logically empiricist heritage. Embracing a religious way of thinking is a matter of choosing a certain linguistic framework, or what Wittgenstein called a language-game (though Wittgenstein never simply spoke about religion as a language-game); as Carnap argued, such choices can only be pragmatically justified. Religious beliefs do not mirror a pre-existing reality but are anchored in human beings' decisions to use certain ways of speaking, or their growing into certain ways of speaking. This, clearly, is more a Wittgensteinian than a Carnapian conception of religion, but it does bear some resemblance to the anti-metaphysical, logical empiricist view on religion as merely poetic language serving purposes quite different from literal, scientific language.
} 
"mine". But this transcendental solipsism no more sacrifices the objectivity of those objects than the transcendental idealism of Kant's First Critique, which is compatible with empirical realism. ${ }^{29}$ This idea is not as foreign to pragmatism as it might seem, either; on the contrary, as soon as pragmatism is reconnected with its Kantian background, something like a Wittgensteinian conception of subjectivity, objectivity, and the world can also, in a rearticulated form, be seen as the core position of a transcendental-pragmatic account of objectivity and subjectivity. Paradoxically (though this cannot be demonstrated here), a pragmatic, naturalized view of the empirical self is fully compatible - and may even require - the idea of a transcendental subject, and even transcendental idealism.

Even this brief discussion of pragmatic objectivity ("without objects") should lead us to reconsider the prospects of metaphysics in the pragmatist tradition, especially in relation to the logical-empiricist dimensions of pragmatism and neopragmatism. At this point, however, a somewhat more extensive excursus to Wittgensteinian aspects of (neo)pragmatism - or, conversely, some strikingly pragmatist themes in Wittgenstein scholarship - is needed in order to shed more light on the metaphysics vs. anti-metaphysics tension I have spoken about. Indeed, Wittgenstein is a major part of the "Viennese background" of neopragmatism.

\section{Wittgenstein and (neo)pragmatism}

Although I just speculated about neopragmatism's possible emergence in relation to the Carnapian principle of tolerance, it could be argued that neopragmatism emerged, instead of 1934, already in 1929-30 when Ludwig Wittgenstein returned to work on philosophical problems after the decade he had, following the publication of the Tractatus, spent as a school teacher in rural Austria. Hence, the Viennese background of neopragmatism could, arguably, be even more important when we consider Wittgenstein's influence on the emergence of neopragmatism. ${ }^{30}$ However, (re)connecting Wittgenstein and pragmatism does not force us to embrace the controversial "resolute reading" of Wittgenstein - a reading to which Putnam has also shown

\footnotetext{
${ }^{29}$ For further elucidation, historical and systematic, see Pihlström (2004).

${ }^{30}$ Note also that Putnam, in one of his many writings on Wittgenstein, brings the later Wittgenstein precisely into the context of discussion shaped by Carnap's and Reichenbach's logical empiricism, more specifically by their discussions of the phenomenalist (egocentric, methodologically solipsist) language and "usual language" (or "thing language"); this is exactly where, he argues, Wittgenstein's treatment of private language and public language becomes urgently relevant (see Putnam 2012, 349-353).
} 
considerable sympathy if not complete acceptance. ${ }^{31}$ One question - continuing to explore Putnam's views as a kind of metonymy of neopragmatism generally - is this: could the tension between Wittgenstein and the mainstream of analytic philosophy that grew out of logical empiricism be analogous to a tension observable within Putnam's neopragmatism between deconstructive (therapeutic) and constructive (systematic, theoretical) philosophy? That is, within Putnam and perhaps neopragmatism more generally we may find a tension between "Wittgensteinian" approaches, on the one hand, and Carnapian and Quinean ones, on the other.

Let us therefore briefly consider Wittgenstein's relation to pragmatism, even though, historically, there is little to be added to the existing scholarship on the relation between Wittgenstein's philosophy and the pragmatist tradition. Russell Goodman's Wittgenstein and William James (2002) tells us most that is worth telling about this issue, at least insofar as we are concerned with Wittgenstein's relation to James. There are, however, a number of both historical and systematic issues in contemporary Wittgenstein scholarship that could be fruitfully reexamined from a pragmatist perspective. For example, several noted scholars (including James Conant, Cora Diamond, and Rupert Read) have suggested that Wittgenstein's philosophy is completely different from any traditional attempts to philosophize in terms of theses and arguments. Those are to be rejected as little more than remnants of "dogmatic" ways of doing philosophy. Instead of engaging with theses and arguments, philosophy should be therapeutical and deconstructive, liberating us from assumptions that lead us to philosophical pseudoproblems. The so-called “New Wittgensteinians”, taking seriously Wittgenstein's encouragement to "drop the ladder" toward the end of the Tractatus and his proposal in the Investigations to lead philosophical thought to "peace", advance this therapeutic-deconstructive program.

From a pragmatist point of view, we can perceive a misleading dichotomous opposition between implausible extremes at work here (see also Putnam 2012, 350). To defend a conception of philosophy as a systematic, argumentative practice employing theses and arguments supporting those theses is not to be a dogmatic believer in any particular philosophical system. As a brief illustration, I would like to suggest that, despite his criticism of traditional ways of doing philosophy, Wittgenstein employs pragmatic versions of transcendental arguments (e.g., the private language argument) in favor of certain philosophical conceptions (e.g., the view that our language is necessarily public). The private language argument can be regarded as transcendental because the fact that language is public is, as a result of this argument, claimed to be a necessary condition for the very possibility of linguistic meaning. A private language

\footnotetext{
${ }^{31}$ Cf. the several essays on Wittgenstein in Putnam (2012). The matter is briefly discussed in my recent paper on Wittgenstein and pragmatism (Pihlström 2012a; cf. also below). In this section, I am borrowing some paragraphs from that essay.
} 
would not be a language at all; as Wittgenstein notes, rules cannot be followed privately. Similarly, it could be argued on the basis of Wittgenstein's On Certainty that, necessarily, there must be agreement about certain apparently empirical matters ("hinges", e.g., our basic conviction about the earth having existed for a long time and not just for, say, five minutes) in order for meaningful use of language to be possible at all. ${ }^{32} \mathrm{I}$ am not making any claims about the success of these or any other Wittgensteinian arguments, but it seems to me clear that Wittgenstein can be plausibly read as employing a "pragmatized" transcendental method of examining the necessary practice-embedded conditions for the possibility of something (e.g., meaningful language) whose actuality we take as given (cf. Pihlström 2003). ${ }^{33}$

Analogously, the pragmatists and neopragmatists themselves can also be reinterpreted as philosophers presenting and evaluating such transcendental arguments (or, more broadly, transcendental considerations and inquiries), even though neopragmatists like Rorty have tried to depict not only Wittgenstein but also James and Dewey in a deconstructive manner, as some kind of precursors of both Wittgensteinian therapy and Derridean deconstruction (and postmodernism generally), which, ironically enough, may not be very far from the Carnapian deconstruction of all allegedly nonsensical metaphysics. For a pragmatist, there is no reason at all to resort to any unpragmatic dichotomy between transcendental philosophical theory and philosophy as a therapeutically relevant practical activity eliminating unnecessary confusions. Rather, philosophical theorizing itself is, inevitably, a practice-embedded human activity with aims ultimately related to our well-being.

A healthy pragmatism should, then, instead of relying on an essentialist dichotomy between post-philosophical therapy and systematic argumentation, insist on the compatibility and deep complementarity of deconstruction and reconstruction. The deconstruction of philosophical problems and ideas should always be followed by a reconstruction. This is in effect what Dewey argued in Reconstruction in Philosophy (1920); as Putnam later put it in Renewing Philosophy (1992), "deconstruction without reconstruction is irresponsibility". The crude

\footnotetext{
32 For a pragmatic approach to On Certainty (Wittgenstein 1969), see Moyal-Sharrock (2003) and (2004), as well as my critical discussion of her interpretation (Pihlström 2012a).

33 Putnam (2012, 563-564), among many others, opposes this transcendental reading of the private language argument, referring to James Conant as one of those who successfully explain it away as a misreading of Wittgenstein. In this discussion - in the context of his insightful engagement with Cavell - Putnam in my view fails to acknowledge the transcendental nature of his own line of thought (attributed to Cavell): “[...] skepticism universalized, skepticism that refuses to acknowledge any human community, is, to the extent that it is possible, a posture that negates not only its own intelligibility but also the very existence of a speaking and thinking subject, negates the skeptic's own existence and the world's" (ibid., 564). I also remain unconvinced by Putnam's claim that Wittgenstein in the Tractatus would have shown transcendental idealism (which Kant had argued to make empirical realism possible) to be "unintelligible nonsense" (ibid., 342). Putnam's "deflationary reading of the supposed 'solipsism' of the Tractatus", as he appropriately labels it, of course goes well together with his stubborn refusal to ever acknowledge transcendental idealism as a background of his own pragmatic or internal realism (cf. also Putnam 2006, responding to my contrary suggestions in Pihlström 2006).
} 
dichotomy between therapeutic and systematic philosophy is completely unpragmatic, as it assumes an essentialistic conception of the proper way of doing philosophy, without letting the richness of different philosophical aims, methods, and conceptions flourish. It thinks before looking, to use a Wittgensteinian phrase; or, to adopt a Peircean expression, it blocks the road of inquiry. Our philosophical inquiries often need both deconstruction and reconstruction; therefore, to one-sidedly restrict proper philosophizing to only one of these impedes philosophical understanding.

Moreover, to raise an issue closely connected with the systematic vs. therapeutic conceptions of philosophy, both Wittgenstein and the pragmatists - no less than the logical empiricists - have been regarded as radically anti-metaphysical thinkers. For instance, Rorty repeatedly pictures both in this fashion, and more recent neopragmatists like Huw Price (2011) share this negative attitude to metaphysics. However, as I have argued earlier (e.g., Pihlström 2009) - but won't be able to argue in detail here - this is a fundamental misrepresentation of pragmatism. The pragmatists - and, perhaps analogously, Wittgenstein - can be seen as offering us a new kind of metaphysics, one based not on the futile attempt to climb above our forms of life into a God's-Eye View but on human practices and especially our practice-embedded ethical standpoints and considerations. Engaging in metaphysics is a way of interpreting our human being-in-the-world, which cannot be separated from ethical values (or other values, including aesthetic ones, for that matter). This general idea is also closely related to the pragmatist rejection of the fact-value dichotomy. ${ }^{34}$

This is, of course, not at all to say that either pragmatists or Wittgenstein would not engage in the criticism of metaphysics. Obviously, they did and do, just like the logical empiricists did. These philosophers both heavily criticize not only specific metaphysical ideas (e.g., Cartesian assumptions in the philosophy of mind or the picture of meanings as mental or abstract entities untouched by the practices of language-use) but also, and more importantly, the very conception of metaphysics based on traditional pre-Kantian metaphysical realism (transcendental realism), just as Kant himself did throughout his critique of reason. However, they need not leave the matter at that point but can offer a reconstructed - or, as we might say, post-Kantian - pragmatic, naturalized yet in a sense transcendental way of doing metaphysics in terms of, and on the basis of, human experiential practices (forms of life, language-games). Pace (say) Price, this is continuing metaphysics "in a pragmatist key" instead of abandoning metaphysics altogether. Pragmatism and Wittgensteinian explorations of fundamental, yet revisable and fallible, features of our forms of life here converge into what we may describe as a

\footnotetext{
${ }^{34}$ Cf., e.g., Putnam's work on this, especially Putnam (2002); see also Pihlström (2005).
} 
pragmatic philosophical anthropology, which, transcendentally interpreted yet pragmatically naturalized, $i$ itself a form of metaphysics. Alternatively, we could speak about the topography - or, with a more evolutionary and dynamic emphasis - the natural history of our forms of life (knowing that Wittgenstein himself was fond of both metaphors).

Moreover, the kind of pragmatism that Wittgenstein and philosophers like James share is deeply pluralistic (cf. again Price 2011, chapters 2 and 10). Both James and Wittgenstein insist on the contextuality and pragmatic circumstantiality of human meanings, thought, and experience; we never encounter the world as it is in itself but always within one or another context - that is, a practice or a form of life. Furthermore, as there is no super-context or practice over and above all others, there is no single correct way of using language or interpreting experience, no privileged representations in the sense of the ideal language isomorphic to the structure of the world that Wittgenstein imagined in the Tractatus; instead, there is a plurality of equally acceptable ways of conceptualizing reality through different pragmatic engagements, each with their own valuational purposes built into them. We should again note how close this view comes to the Carnapian pluralism about linguistic frameworks. These may be related to each other through networks of family resemblances (to use Wittgenstein's well-known concept). ${ }^{35}$ Language-games (or linguistic frameworks) are not mirrors of an independent reality, and there is no way of representing the world from a God's-Eye View; instead, there are only human, contextual, pragmatically embedded perspectives from within our forms of life.

We may here draw support from Putnam's account of Wittgenstein's relation to Kant and pragmatism (thereby highlighting Putnam's own appreciation of a kind of "Viennese background" of his own neopragmatism): "Wittgenstein inherits and extends [...] Kant's pluralism; that is the idea that no one language game deserves the exclusive right to be called 'true', or 'rational', or 'our first-class conceptual system', or the system that 'limns the ultimate nature of reality', or anything like that." (Putnam 1992, 38.) Putnam continues to observe - very interestingly from the perspective of the proposal to integrate Wittgenstein into the pragmatist tradition - that for this reason Wittgenstein can be said to refute key ideas propounded by two leading twentieth-century pragmatists, i.e., both Quine's reductive naturalism and Rorty's relativistic and postmodernist neopragmatism: “[...] he agrees with Rorty, against Quine, that one cannot say that scientific language games are the only language games in which we say or write truths, or in which we describe reality; but, on the other hand, he agrees with Quine as against

\footnotetext{
35 Wittgenstein may even have derived the notion of a family resemblance from pragmatism, that is, from William James's Varieties of Religious Experience (1902), which he is known to have read carefully. See Goodman (2002).
} 
Rorty that language games can be criticized (or 'combatted'); that there are better and worse language games." (Ibid.) $)^{36}$

Arguably, a Wittgensteinian pragmatist may hold that our practice-embedded perspectives may, and often do, yield (or presuppose) metaphysical insights into the way the world is, or must be thought to be (by us), from within the various practical contexts we operate in. These are not insights into the world as it is absolutely independently of our conceptualizing practices and (ethically or more generally valuationally laden) practical points of view, but they are metaphysical insights nonetheless. For example, the well-known Wittgensteinian view (if we may say that Wittgenstein ever maintained philosophical views) ${ }^{37}$ that there can be no private language in the sense of a language that only its speaker could ever understand or learn to use, just like the pragmatically pluralistic thesis derivable from the Putnamian interpretation just cited, can be interpreted as a metaphysical thesis about the way the world, including language and our life with language, is, for us language-users in the kind of natural circumstances and contexts (forms of life) we are in. In this sense, both pragmatism and Wittgenstein can be understood as critically rethinking the nature of metaphysics - and anti-metaphysics - rather than simply moving beyond metaphysics.

There are also other debates in Wittgenstein scholarship to which a (neo)pragmatist perspective would offer insightful (but often neglected) perspectives. For instance, two other key issues of Wittgenstein studies provide particularly useful insights into the ways in which Wittgenstein, or the contemporary "Wittgensteinian" philosopher, could be regarded as a pragmatist: the distinction - invoked in recent discussions of On Certainty, in particular - between the propositional and the non-propositional (see again Moyal-Sharrock 2003, 2004); and the related tension between anti-Cartesian fallibilism and what has been called (by Stanley Cavell) the "truth in skepticism" in Wittgenstein. ${ }^{38} \mathrm{I}$ believe it can be plausibly argued that dichotomous readings of Wittgenstein in terms of these philosophical (or metaphilosophical) oppositions lead to unpragmatist and even un-Wittgensteinian positions, just as the dichotomies between theoretical (constructive) and therapeutic (deconstructive) or between metaphysical and anti-metaphysical approaches do.

\footnotetext{
${ }^{36}$ Note, again, that it is far from clear that Quine can be called a "pragmatist" at all, despite his influence on both Putnam's and Rorty's versions of neopragmatism. See Koskinen and Pihlström (2006).

${ }^{37}$ I am fully aware that some New Wittgensteinians resist such formulations.

${ }^{38}$ Putnam $(2012,563)$ perceptively notes that Cavell's work also aspires to "get us to see than an idea of being totally free of skepticism [in the deep sense of failing to acknowledge the suffering of others] is itself a form of skepticism." The key reference here is, obviously, Cavell (1979).
} 


\section{Holistic pragmatism}

As we have seen, there are both metaphysical and anti-metaphysical elements in the kind of (e.g., Putnamian) neopragmatism that organically grows out of (Carnapian) logical empiricism while abandoning its total elimination of metaphysics. How to weigh these different views as parts of one and the same pragmatist overall approach? In brief, how to integrate metaphysics with antimetaphysics? In considering this question, I now want to move on from the Putnamian position toward another type of (neo)pragmatism that may be more promising in offering such an integration.

One suggestion for a way of developing an integrated pragmatist approach, returning to the original rendezvous of pragmatism and logical empiricism, is Morton White's $(1956,2002)$ bolistic pragmatism, which is basically an epistemological position but can be extended to a holistically pragmatist ontology of culture as well as, possibly, to a metaphilosophical account of what is correct and incorrect in both metaphysics and anti-metaphysics. ${ }^{39}$ In a Quinean manner, White labels his pragmatism "holistic"; like Quine, he follows the antiCartesian and more generally anti-rationalist line of pragmatist thought (White 2002, 3-5), abandoning any "first philosophy". The specific nature of White's position emerges against the background of Quine's more extreme views. While both Quine and White begin from a firm rejection of the analytic/synthetic distinction and from the holistic idea that our beliefs (or sentences) are not tested individually but "face the tribunal of experience" in corporate bodies, they draw quite different morals from this picture.

Whereas philosophy of science is, for Quine, philosophy enough, White proposes the kind of holistic approach Quine favors in the philosophy of science to be developed into a philosophy of culture, examining not only science - as logical empiricism primarily did - but also religion, history, art, law, and morality (ibid., x-xi). This "cultural philosophy" covers philosophy of science as one of its subfields - science, of course, is part of culture, something that human beings "cultivate" - but White insists that other cultural institutions require empirically informed philosophical scrutiny no less than science does (ibid., xiii). In this sense White crucially extends the scope of philosophical activity from the logical-empiricist focus on the philosophy of science, which, for Quine, was "philosophy enough". ${ }^{40}$ Holistic pragmatism says that "philosophy of art, of religion, of morality, or of other elements of culture is in great measure a discipline that is

\footnotetext{
39 White, of course, was also a key mediating figure between logical empiricism and pragmatism, along with philosophers like Lewis, Nagel, Quine, and Goodman. For an excellent recent discussion, see Sinclair (2011). Cf. also my recent paper on White (Pihlström 2011), on which I to some extent rely here, as well as, again, Koskinen and Pihlström (2006) on Quine and pragmatism.

${ }^{40}$ See Quine (1953b); cf. Isaacson (2004), 245.
} 
epistemically coordinate with philosophy of natural science" (ibid., 66). Quine's way of restricting his philosophical concerns to science should be abandoned as one more unfortunate and by no means necessary remnant from logical positivism (ibid., 3). The idea that ethics, in particular, "may be viewed as empirical if one includes feelings of moral obligation as well as sensory experiences in the pool or flux into which the ethical believer worked a manageable structure" has been strongly present in White's writings from an early stage to the present (see White 1956, 1981, 2002, passim). This can be regarded as the main novelty in his thought in relation to previous pragmatic holists like Quine.

Quine (1953a) took his famous holistic step by arguing that even logical truths are not immune to revision, because they are tested along with factual claims as components of a large conjunction of statements (White 2002, 71). No general analytic/synthetic division can be drawn, as statements about, say, the synonymity of terms are ultimately empirical statements describing the contingencies of factual language-use (ibid., 71, 73). Despite this fundamental agreement with Quine, White argues that "observation sentences" (e.g., "That's a rabbit") and ethical sentences such as "That's outrageous" cannot be sharply separated from each other any more than analytic and synthetic statements can; their difference is a matter of degree instead of being a difference in kind (ibid., 154-155, 160-163). The ethical sentences at issue are, moreover, genuinely normative: "Avoiding the view that ethical sentences are synonymous with sociological or psychological sentences, and being impressed by the failure of reductive phenomenalism as well as the power of holism to bridge the traditional epistemic gap created by the distinction between the analytic and the synthetic, I propose a nonreductive version of holism in order to bridge the gap between the moral and the descriptive [...].” (Ibid., 157.)

That is, descriptive statements and normative ethical principles form conjunctions that are tested holistically, just as Quine had argued that scientific and logico-mathematical beliefs in science are. Logic, science, and ethics form a unified whole, a holistic web without epistemic dichotomies. Moreover, as logical principles may, by Quinean lights, be given up in the face of sufficiently recalcitrant experience, descriptive statements may be denied in order to preserve a normative principle we do not want to give up (ibid., 159), although such situations are rare. White's point is that ethics is not inferior to science, or immune to empirical evaluation, because feelings of obligation together with sensory observation link ethical sentences to the natural world. Pace Quine, ethics is, then, "anchored in experience" (ibid., 160). Ethics is a "soft science" rather than a "hard" one, but it is a science nonetheless, hardly any softer than Quine's own naturalized "epistemological science", the branch of psychology studying human cognition (ibid., 161-162). Furthermore, "feeling sentences" are also fallible and can be surrendered when a 
conjunction is tested (ibid., 166). Both ethics and science are, then, corrigible but cognitive enterprises - just like classical pragmatists like Dewey maintained. Both are elements of human culture that in the end forms a holistic totality instead of any compartmentalized group of distinct areas with definite boundaries. Knowledge and morals, as White himself formulated his point many years ago, form a "seamless web" (White 1956, 287).

I would be happy to construe this view more metaphysically as a thesis about there being no "value-neutral" facts at all (see Pihlström 2005, 2010); however, I doubt that White himself ever intended it in such a metaphysical sense. In any case, White's holism could be extended from the epistemic justification of different kinds of statements (sentences) to whatever is the equivalent of such normative justification in the critical evaluation of entire cultural practices and institutions. While remaining distinct from each other, such practices (e.g., science, politics, religion, art, and others) are dynamically interrelated and must therefore be "tested" holistically whatever it ultimately means to "test" them. One way of supplementing White's holistic ethicsscience "corporatism" would, indeed, be the addition of pragmatist metaphysics into the picture - yielding an even more comprehensive form of holistic pragmatism. One may argue that White himself (just like Putnam in the end) is too faithful a disciple of logical empiricism because he simply goes too far in the somewhat dogmatic project of avoiding metaphysics at all costs. ${ }^{41}$

Accordingly, also metaphysical statements, like scientific and ethical ones, can thus be holistically evaluated in the pragmatic way White suggests. Pragmatist metaphysics itself can be holistically developed; however, one may argue that it must not be holistic in a monistic way (as in Hegelian holistic idealism criticized by the pragmatists) but genuinely pluralistic, as James famously maintained in Pragmatism and elsewhere. Furthermore, a pragmatist metaphysics of culture must differ, crucially, from metaphysically realistic approaches, in which the nature of cultural entities is examined on the basis of a metaphysical scheme presupposed to be true from a "God's-Eye View". Both reductionist (naturalist) and anti-reductionist (e.g., Platonist?) positions here typically turn out to presuppose such metaphysically realist background assumptions, which the pragmatist must firmly reject. (The pragmatist also rejects, following Dewey, any principled, essentialist dichotomy between culture and nature.) However, pragmatist metaphysics (in the way I am developing it) is a species of transcendental idealism, reinterpreted as transcendental pragmatism. This approach makes ontological/metaphysical postulations and

\footnotetext{
${ }^{41}$ I would thus not suggest that we follow him into, say, the claim that there is no pragmatic difference between Peircean scholastic realism and nominalism (see again White 2002). On the contrary, there is a major pragmatic difference between these positions - but these (and other) metaphysical views indeed have to be understood pragmatically, not as metaphysical theories independent of pragmatic and hence eventually broadly cultural considerations.
} 
commitments dependent on not just linguistic frameworks but more generally human purposive practices - thus on human culture in a broad sense.

Does this lead to a problematic circular structure in our metaphysical system? A further pragmatist inquiry ought to be devoted to analyzing this threat of circularity that seems to emerge from the position sketched here, showing that the relevant kind of circularity at issue need not be vicious but can in fact be self-strengthening. Thus, we begin to notice how the metaphysical relevance of contemporary - originally heavily logical-empiricism-involving neopragmatism extends from a core position such as Putnam's conceptual relativity to various "surrounding" views and ideas that often incorporate rich positions on the human condition. Certainly no formal investigation of linguistic frameworks and their logical structures is sufficient to settle the neopragmatist issue of realism vs. antirealism, or neopragmatist tensions between metaphysics and anti-metaphysics.

Similarly (returning to concerns raised earlier in this paper), Putnam's account of conceptual relativity should in my view be developed in ways that Putnam himself doesn't find congenial: first, it should be seen as metaphysically relevant, despite Putnam's residual logical empiricism (i.e., Carnapianism); and secondly, it should be rearticulated as a pragmatized version of transcendental idealism, despite Putnam's desire to avoid all talk about the "transcendental" (as well as any kind of idealism). ${ }^{42} \mathrm{~A}$ full development of these themes would, however, require a book-length study. Let me just here assure you that the metaphysical relevance of Putnam's neopragmatism actually goes well together with the transcendentally idealist reinterpretation of his pragmatic realism, insofar as transcendental idealism itself is a (benign) metaphysical view. This requires, however, that we also give up those interpretations of transcendental idealism itself that treat it as "merely methodological". Pace Henry Allison (2004), we have to view transcendental idealism, even in its pragmatic rearticulations, as a metaphysically relevant approach to the way the world must be categorized by human beings in order for it to be cognitively experienceable. Here, again, we see how systematic inquiries into realism and other issues in contemporary philosophy need historical backing - and ultimately we need to go all the way back to Kant, not just back to logical empiricism or classical pragmatism.

\footnotetext{
42 As is well known, logical empiricism has recently been observed to have been more strongly neo-Kantian than the received view construes it as being - see, e.g., Friedman (2001) and Richardson (1998) - and the same, arguably, applies to pragmatism and neopragmatism - see Pihlström (2003) and (2009). Indeed, insofar as this neo-Kantian emphasis is on the right track, neopragmatism may be considerably more Kantian than the leading neopragmatists themselves, especially Rorty but even Putnam, have ever acknowledged. On the neo-Kantian character of logical empiricist philosophy of science comparable to Kuhn's "new" philosophy of science (and, hence, pragmatism), see also Pihlström and Siitonen (2005).
} 


\section{Conclusion}

Contemporary pragmatism and neopragmatism should recognize not only their roots at Harvard (e.g., Peirce, James, Lewis) and Columbia (e.g., Dewey, Nagel) but also their logical-empiricist Viennese background - and should do so in many areas: in metaphysics, anti-metaphysics, epistemology, philosophy of science, ethics, and philosophy of religion, among others. This paper has largely, though not exclusively, focused on Putnam's neopragmatism, which is a highly illuminating case because of its indebtedness to Carnap's ideas of "tolerance" and linguistic frameworks; however, the moral of the paper is more general. Pragmatism is at its best when it flexibly engages in collaboration with other philosophical orientations - including not only analytic philosophy but also phenomenology, hermeneutics, critical theory, and other approaches - while maintaining its own identity. There is much more work to do here. The various pragmatist themes in Wittgenstein scholarship only briefly and tentatively discussed above should be investigated further. White's holism should be formulated with greater precision. And so forth. Pragmatism, moreover, ought to speak - and also listen - not only to the well-known philosophical orientations today, such as analytic philosophy or phenomenology, but also to the marginalized, forgotten, and eclipsed ones, whether or not pragmatism itself was ever truly eclipsed by logical empiricism or analytic philosophy.

\section{Acknowledgments}

This paper is based on a presentation at the workshop, Pragmatism and Logical Empiricism, Vienna Circle Institute, University of Vienna (November 8-9, 2013). Related material was also presented at the conference, Philosophical Revolutions, University College Dublin (June, 2013). I should like to thank Maria Baghramian, Sarin Marchetti, Larry Hickman, Friedrich Stadler, Ilkka Niiniluoto, and Heikki J. Koskinen, among many others, for valuable comments and discussion. I also gratefully acknowledge the critical comments by an anonymous referee.

\section{References}

Allison, Henry (2004), Kant's Transcendental Idealism: An Interpretation and Defense - A Revised and Enlarged Edition. New Haven, CT and London: Yale University Press. (1 ${ }^{\text {st }}$ ed. 1983.)

Ayer, A.J. (1936), Language, Truth and Logic. Harmondsworth: Penguin, 1986.

Burke, F. Thomas (2013), What Pragmatism Was. Bloomington: Indiana University Press. 
Carnap, Rudolf (1934), Logische Syntax der Sprache. Wien: Springer.

--- (1950), "Empiricism, Semantics, and Ontology", in Leonard Linsky (ed.), Semantics and the Philosophy of Language. Urbana: University of Illinois Press, 1952, 208-228. (Originally published in Revue Internationale de Philosophie 11.)

--- (1963), "Replies and Systematic Expositions", in Paul Arthur Schilpp (ed.), The Philosophy of Rudolf Carnap. La Salle,

IL: Open Court, 859-1013.

--- (1967), The Logical Structure of the World \& Pseudoproblems in Philosophy, trans. Rolf A. George. Berkeley and Los Angeles: University of California Press. (Originally published as Der logische Aufbau der Welt, 1928.)

Cavell, Stanley (1979), The Claim of Reason. New York: Oxford University Press.

Creath, Richard (ed.) (1990), Dear Carnap, Dear Van: The Quine - Carnap Correspondence and Related Work. Berkeley: University of California Press.

--- (2007), "Vienna, the City of Quine's Dreams", in Richardon and Uebel (2007), 332-345.

da Cunha, Ivan Ferreira (2012), "John Dewey and the Logical Empiricist Unity of Science”, Cognitio 13, $219-230$.

Dewey, John (1938), "Unity of Science as a Social Problem", International Encyclopedia of Unified Science 1:1, 29-38.

--- (1939), "Theory of Valuation”, International Encyclopedia of Unified Science 2:4. Chicago: University of Chicago Press.

Friedman, Michael (2001), Dynamics of Reason. Stanford, CA: CSLI Publications.

--- (2003), "Kuhn and Logical Empiricism", in Thomas Nickels (ed.), Thomas Kubn. Cambridge: Cambridge University Press, 19-44.

--- (2007), "Coordination, Constitution, and Convention: The Evolution of the A Priori in Logical Empiricism", in Richardson and Uebel (2007), 91-116.

Giere, Ronald N. and Richardson, Alan W. (eds.) (1996), Origins of Logical Empiricism. Minnesota Studies in the Philosophy of Science 16. Minneapolis and London: University of Minnesota Press.

Goodman, Nelson (1978), Ways of Worldmaking. Hassocks: The Harvester Press.

Goodman, Russell B. (2002), Wittgenstein and William James. Cambridge: Cambridge University Press.

Haaparanta, Leila and Koskinen, Heikki J. (eds.) (2012), Categories of Being: Essays on Metaphysics and Logic. New York: Oxford University Press.

Hickman, Larry (2007), Pragmatism as Post-Postmodernism: Lessons from Dewey. New York: Fordham University Press.

Hildebrand, David (2003), Beyond Realism and Antirealism: Dewey and the Neopragmatists. Nashville, TN: Vanderbilt University Press.

Holton, Gerald (1993), "From the Vienna Circle to Harvard Square: The Americanization of a European World Conception”, in Friedrich Stadler (ed.), Scientific Philosophy: Origins and Developments. Dordrecht: Kluwer, 47-73.

Isaacson, Daniel (2004), “Quine and Logical Positivism”, in Roger F. Gibson (ed.), The Cambridge Companion to Quine. Cambridge: Cambridge University Press, 214-269.

James, William (1907), Pragmatism: A New Name for Some Old Ways of Thinking. Eds. Frederick H. Burkhardt, Fredson Bowers, and Ignas K. Skrupskelis. Cambridge, MA and London: Harvard University Press, 1975.

Janik, Allan and Toulmin, Stephen (1973), Wittgenstein's Vienna. New York: Simon \& Schuster.

Järvilehto, Lauri (2011), Pragmatic A Priori Knowledge: A Pragmatic Approach to the Nature and Object of What Can Be Known Independently of Experience. Jyväskylä Studies in Education, Psychology and Social Research 429. Jyväskylä: University of Jyväskylä. (Ph.D. Diss.)

Kant, Immanuel (1781/1787), Kritik der reinen Vernunft, ed. Raymund Schmidt. Hamburg: Felix Meiner, 1990.

Kitcher, Philip (2013), Preludes to Pragmatism. Oxford: Oxford University Press.

Koskinen, Heikki J. (2004), From a Metaphilosophical Point of View: A Study of W.V. Quine's Naturalism. Acta Philosophica Fennica. Helsinki: The Philosophical Society of Finland. 
--- and Pihlström, Sami (2006), “Quine and Pragmatism”, Transactions of the Charles S. Peirce Society ...

Lewis, C.I. (1923), “A Pragmatic Conception of the A Priori”, The Journal of Philosophy 20, 169-177.

Limbeck-Lilienau, Christoph (2012), “Carnap's Encounter with Pragmatism”, in Richard Creath (ed.), Rudolf Carnap and the Legacy of Logical Empiricism. Vienna Circle Institute Yearbook 16. Dordrecht: Springer, 89-110.

Mackie, J.L. (1977), Ethics: Inventing Right and Wrong. Harmondsworth: Penguin.

Misak, Cheryl (ed.) (2007), New Pragmatists. Oxford: Oxford University Press.

--- (2013), The American Pragmatists. Oxford: Oxford University Press.

Mormann, Thomas (2012), "Toward a Theory of the Pragmatic A Priori: From Carnap to Lewis and Beyond", in Richard Creath (ed.), Rudolf Carnap and the Legacy of Logical Empiricism. Vienna Circle Institute Yearbook 16. Dordrecht: Springer, 113-132.

Morris, Charles (1928), "Neopragmatism and the Ways of Knowing", The Monist 38, 494-510.

--- (1934), "Pragmatism and Metaphysics", The Philosophical Review 43:6, 149-164.

--- (1937), "The Concept of Meaning in Pragmatism and Logical Positivism", in Amelie Rorty (ed.), Pragmatic Philosophy: An Anthology. Garden City, NY: Doubleday \& Co., 1966, 374-381.

--- (1938), "Peirce, Mead, and Pragmatism", The Philosophical Review 47, $109-127$.

--- (1963), "Pragmatism and Logical Empiricism", in Paul Arthur Schilpp (ed.), The Philosophy of Rudolf Carnap. La Salle, IL: Open Court, 87-98.

Moyal-Sharrock, Danièle (2004), The Third Wittgenstein. Basingstoke: Palgrave.

Nagel, Ernest (1940), "Charles S. Peirce, Pioneer of Modern Empiricism", in Ernest Nagel, Sovereign Reasons. Glencoe, IL: The Free Press, 89-100.

Niiniluoto, Ilkka (1992), "Eino Kaila and Scientific Realism", in Niiniluoto et al. (1992), 102-116.

--- (1999), Critical Scientific Realism. Oxford: Oxford University Press.

---, Sintonen, Matti, and von Wright, Georg Henrik (eds.) (1992), Eino Kaila and Logical Empiricism. Acta Philosophica Fennica 52. Helsinki: The Philosophical Society of Finland.

--- and Pihlström, Sami (eds.) (2012), Reappraisals of Eino Kaila's Philosophy. Acta Philosophica Fennica 89. Helsinki: The Philosophical Society of Finland.

Peirce, Charles S. (1992-98), The Essential Peirce, 2 vols. The Peirce Edition Project. Bloomington: Indiana University Press.

Pihlström, Sami (1996), Structuring the World: The Issue of Realism and the Nature of Ontological Problems in Classical and Contemporary Pragmatism. Acta Philosophica Fennica 59. Helsinki: The Philosophical Society of Finland.

--- (2003), Naturalizing the Transcendental: A Pragmatic View. Amherst, NY: Prometheus/Humanity Books.

--- (2004), "Putnam and Rorty on Their Pragmatist Heritage: Re-reading James and Dewey", in Elias L. Khalil (ed.),

Dewey, Pragmatism, and Economic Methodology. London and New York: Routledge.

--- (2005), Pragmatic Moral Realism: A Transcendental Defense. Amsterdam and New York: Rodopi.

--- (2006), "Putnam's Conception of Ontology", Contemporary Pragmatism 3.

--- (2008), "How (Not) to Write the History of Pragmatist Philosophy of Science?”, Perspectives on Science 16, 26-69.

--- (2009), Pragmatist Metaphysics: An Essay on the Ethical Grounds of Ontology. London: Continuum.

--- (2010), "Emergence or Continuity? Toward a Pragmatist Metaphysics of the Fact-Value Entanglement", Journal of Philosophical Research 35.

--- (2011), "Morton White's Philosophy of Culture: Holistic Pragmatism and Interdisciplinary Inquiry", Human Affairs 21.

--- (ed.) (2011), The Continuum Companion to Pragmatism. London: Continuum. (Paperback edition, The Bloomsbury Companion to Pragmatism, forthcoming in 2015. London: Bloomsbury.)

--- (2012a), “A New Look at Wittgenstein and Pragmatism”, European Journal of Pragmatism and American Philosophy 4:2, www.journalofpragmatism.eu.

--- (2012b), "Toward a Pragmatically Naturalized Transcendental Philosophy of Science and Pragmatic Scientific Realism", Studia Philosophia Estonica 5.

--- (2013), Pragmatic Pluralism and the Problem of God. New York: Fordham University Press.

Pihlström, Sami and Siitonen, Arto (2005), "The Transcendental Method in Post-Empiricist Philosophy of Science", Journal for General Philosophy of Science 36. 
Putnam, Hilary (1981), Reason, Truth and History. Cambridge: Cambridge University Press.

--- (1987), The Many Faces of Realism. La Salle, IL: Open Court.

--- (1990), Realism with a Human Face. Ed. James Conant. Cambridge, MA and London: Harvard University Press.

--- (1992), Renewing Philosophy. Cambridge, MA and London: Harvard University Press.

--- (1994), Words and Life. Ed. James Conant. Cambridge, MA and London: Harvard University Press.

--- (1995), Pragmatism: An Open Question. Oxford and Cambridge, MA: Blackwell.

--- (2002), The Collapse of the Fact/V alue Dichotomy and Other Essays. Cambridge, MA and London: Harvard University

Press.

--- (2004), Ethics without Ontology. Cambridge, MA and London: Harvard University Press.

--- (2006), "Responses", Contemporary Pragmatism 3.

--- (2012), Philosophy in an Age of Science. Eds. Mario De Caro and David Macarthur. Cambridge, MA and London: Harvard University Press.

Quine, W.V. (1953a), From a Logical Point of View. Cambridge, MA: Harvard University Press, rev. ed. 1980.

--- (1953b), "Mr. Strawson on Logical Theory", Mind 62, 433-451.

---(1969), Ontological Relativity and Other Essays. New York: Columbia University Press.

Ramsey, Frank Plumpton (1927), "Facts and Propositions", in F.P. Ramsey, Philosophical Papers, ed. D.H. Mellor. Cambridge: Cambridge University Press, 1990, 34-51.

Reichenbach, Hans (1939), "Dewey's Theory of Science", in Paul Arthur Schilpp (ed.), The Philosophy of John Dewey. La Salle, IL: Open Court, 3 ${ }^{\text {rd }}$ ed., 1989, 159-192.

Richardson, Alan W. (1998), Carnap's Construction of the World: The Aufbau and the Emergence of Logical Empiricism. Cambridge: Cambridge University Press.

--- (2007), “That Sort of Everyday Image of Logical Positivism': Thomas Kuhn and the Decline of Logical Empiricist Philosophy of Science", in Richardson and Uebel (2007), 346-370.

--- and Uebel, Thomas (eds.) (2007), The Cambridge Companion to Logical Empiricism. Cambridge: Cambridge University Press.

Rorty, Richard (1979), Philosophy and the Mirror of Nature. Princeton, NJ: Princeton University Press.

Rydenfelt, Henrik and Pihlström, Sami (eds.) (2013), William James on Religion. Basingstoke: Palgrave Macmillan.

Schlick, Moritz (1932-33), "Positivism and Realism", trans. Peter Heath. In Richard Boyd et al. (eds.), The Philosophy of Science. Cambridge, MA and London: The MIT Press, 1991, 37-55.

Shook, John R. (1998), Pragmatism: An Annotated Bibliography 1898-1940. Amsterdam and Atlanta: Rodopi.

Sinclair, Robert (2011), "Morton White’s Moral Pragmatism”, Cognitio 12, 143-155.

--- (2013), "Quine and Conceptual Pragmatism", forthcoming in Transactions of the Charles S. Peirce Society.

Uebel, Thomas (1992), Overcoming Logical Positivism from Within: The Emergence of Neurath's Naturalism in the Vienna Circle's Protocol Sentence Debate. Atlanta: Rodopi.

--- (1996), “The Enlightenment Ambition of Epistemic Utopianism: Otto Neurath's Theory of Science in Historical Perspective", in Giere and Richardson (eds.), 91-112.

Westphal, Kenneth R. (2003), “Can Pragmatic Realists Argue Transcendentally?”, in John R. Shook (ed.), Pragmatic Naturalism and Realism. Amherst, NY: Prometheus.

White, Morton (1956), Toward Reunion in Philosophy. Cambridge, MA: Harvard University Press. --- (2002), A Philosophy of Culture: The Scope of Holistic Pragmatism. Princeton, NJ: Princeton University Press.

Wittgenstein, Ludwig (1921), Tractatus logico-philosophicus: Logisch-philosophische Abhandlung. Frankfurt am Main: Suhrkamp, 1961.

--- (1953), Philosophical Investigations. Trans. G.E.M. Anscombe. Oxford: Basil Blackwell, 1958.

--- (1969), On Certainty. Trans. G.E.M. Anscombe and D. Paul. Oxford: Basil Blackwell. 